\title{
New Exploration on the Path of Construction of the Academic Research Oriented Graduate Students' Party branch under the Guidance of Innovative Ideas
}

\author{
Yiping Chen, Fu Zhou
}

School of Marxism, Wuhan University of Technology, Wuhan 430071, China.

\begin{abstract}
Talent is the soul of national development, innovation is the motive force of social progress, graduate education is an important process of national's culturing high level talents, the construction of graduate student Party branch is an important part of postgraduate education and training system. Under the new situation, University Graduate Student Party branch construction facing new challenge, need in under the guidance of the innovation thought, innovation organization construction, activity carriers and management mode, actively building the Party branch of academic, to further develop the important role of construction of graduate student Party branch in the study of students cultivating.
\end{abstract}

Keywords: Innovation thought; academic scientific research type; graduate student; party branch.

\section{创新思想引领下的学术科研型研究生 \\ 党支部建设路径新探}

\author{
陈意萍，周福 \\ 武汉理工大学, 武汉 中国
}

摘要: 人才是国家发展的灵魂, 创新是社会进步的动力, 研究生教育是国家培养高层次人才 的重要过程, 研究生党支部建设更是研究生教育培养体系的重要组成部分。新形势下, 高校 研究生党支部建设面临着新的挑战, 需要在创新思想引领下, 不断创新组织建设、活动载体 以及管理模式, 积极建设学术科研型党支部, 进一步发挥研究生党支部建设在研究生培养中 的重要作用。

关键词：创新思想；学术科研型；研究生；党支部

\section{1. 前言}

随着研究生队伍的不断壮大, 研究生党支部建设面临组织建设松散、党员思想多元、活 动凝聚力下降等系列挑战。研究生阶段的主要任务是专业学习, 研究生党支部活动的参与度 不高, 党组织的凝聚力有待加强。建设学术科研型党支部, 将支部建设与学术科研相结合是 促进研究生党支部建设的可行之路。

\section{2. 改进研究生党支部建设模式的现实背景}

首先, 改革现阶段研究生党支部建设是时代的要求。十八大提出两个一百年的建设目标, “十三五” 时期正是全面建成小康社会发展目标的决胜时期, 高层次专门人才供不应求, 在经 济的发展和社会的进步对教育表现出前所未有的依赖和期盼的情况下, 研究生培养工作面临 着历史性的大好机遇。研究生党支部建设应与研究生培养整体目标相协调, 积极建立学术科 研型党支部, 将党支部建设与研究生专业发展相结合, 促进研究生人才培养, 为国家社会的 建设输出高质量人才。

其次, 研究生党员的新特点要求改进研究生党支部建设模式。随着研究生队伍的不断壮 大, 研究生党员呈现出新特点：第一, 党员流动性较大, 组织凝聚力下降。以往的党支部建 
设往往采取支部建在年级、支部建在班级的模式, 但研究生班级、年级往往存在着多个学科 专业, 多个研究方向, 课程设置及时间安排不一, 以往的支部组织建设方式导致党支部内部 党员流动性较大, 组织凝聚力下降。第二, 注重专业学习, 忽视政治学习。研究生阶段的主 要任务是专业学习, 研究生党支部党员将更多精力放在了专业课程的学习上, 由于本科阶段 已较完善地掌握相关政治理论知识, 因而对党的最新理论成果存在学习不足的现象。第三, 思想活跃, 主体性意识增强。以往单纯以政治理论学习为主要内容的党支部活动模式对研究 生党员吸引力下降, 研究生党员对于能够充分运用所学专业知识, 调动思维能力的党支部活 动需求量增加。第四, 研究生党员整体素质不一。研究生党员政治素质和专业素质整体上较 高, 但由于研究生队伍的扩招, 本科阶段各高校对于党员的选拔、培养标准不一, 导致研究 生党员在政治素质和专业素质上存在着一定差异。

\section{3. 学术科研型研究生党支部概念界定}

现阶段研究生培育的新形势以及研究生党支部的新特点要求加强学术科研型党支部的建 设。学术科研型党支部并不是党支部性质的改变, 而是在创新思想指导下, 对党组织原有的 组织形式、制度建设、活动方式、管理模式、学习理念进行创新和完善, 不断提升研究生党员 政治理论素质, 同时不断强化研究生党支部在科研活动中和学术研究中的战斗堡垒作用。学 术科研型党支部具体存在以下几方面的特点:

3. 1. 重视政治理论学习

基层党组织的基本任务之一是组织党员认真学习马克思列宁主义、毛泽东思想、邓小平 理论、“三个代表” 重要思想和科学发展观, 学习党的路线、方针、政策和决议, 学习党的 基本知识, 学习科学、文化、法律和业务知识。加强政治理论学习, 提升党员政治理论素养 是基层党支部建设的基础, 是党支部建设在任何时候都不能忽视的工作。只有不断加强政治 理论学习, 才能时刻保持党员先进性, 发挥党支部的战斗堡垒作用。

3. 2. 注重学科专业能力培养

研究生阶段是国家培养输出高层次人才的重要阶段, 专业能力培养是研究生阶段的主要 任务。学术科研型研究生党支部的建设充分注重研究生党员专业能力的培养, 根据研究生党 员学科特点创新组织建设模式, 创新党支部活动内容, 灵活党支部活动开展方式, 形成以科 研促党建, 以党建带科研的支部建设模式。

3. 3. 注重发挥研究生党员创造力

研究生党员具备较高的综合素质, 思维灵活, 自主性较强。学术科研型党支部充分发挥 研究生思维创造力, 改变传统支部政治理论学习模式, 通过互动、演讲、比赛等模式学习党 的先进理论, 并积极将学术科研与支部学习相结合题。

3. 4. 党支部管理的灵活性

网络信息技术发展日新月异, 研究生党员作为高层次人才对网络信息技术也有较为完善 的掌握。学术科研型研究生党支部充分利用网络信息技术开展支部建设, 将网络信息技术运 用到支部活动、政治学习、党员管理中, 促进党支部管理的灵活性。

\section{4. 创新思想引领下的学术科研型研究生党支部建设路径探索}

4. 1. 党支部组织设置与专业设置相结合

以往采取以班级、年级为单位的横向设置基层党组织的形式已不适应研究生阶段党建工 作新特点。适应研究生学科专业划分明显的特点, 以学科方向、实验室、工作室等为单位采 取纵向形式设置基层党支部, 建立学术科研型研究生党支部, 是党支部组织建设新思路。纵 向设置党支部一方面能克服研究生同一班级、年级内专业、学科方向多样化带来的党支部成 员课程时间安排不一的问题, 保证党支部成员的稳定性, 保证党支部活动开展的参与性; 另 一方面, 以学科方向为单位设置党支部能充分调动相关专业研究生导师在党支部建设、研究 
生党员培养中的积极作用, 研究生导师是研究生培养过程中的第一负责人, 对研究生的个人 成长具有重要作用。调动导师参与支部活动, 给予支部活动专业的指导, 促进支部活动与学 术科研相结合, 有利于学术科研型研究生党支部的建设。

4. 2. 党支部活动开展与学术科研相结合

建设学术科研型研究生党支部, 丰富党支部活动形式, 一方面可将党支部政治学习与学 术科研相结合, 改变过去单纯通过民主生活会学习政治理论的形式, 将政治理论学习过程变 为学术科研的过程, 查阅文献并最终形成学术成果; 另一方面, 建立以学术科研成果为重要 衡量标准的评价体系, 在发展党员、评优评先时, 将学术科研成果作为重要评价标准。将党 支部活动开展与学术科研相结合, 符合研究生阶段重学术科研的特点, 不仅能充分调动支部 党员活动参与积极性, 将党建工作与业务培养相结合, 还能丰富党支部建设成果, 促进各级 党建工作的开展。

4. 3. 党支部日常管理与网络信息相结合

由于学术科研需要, 研究生党员除了日常的课程学习, 还有经常性参加学术会议、出差 等事宜, 党员流动性较大, 为加强党员日常管理, 建立学术科研型研究生党支部, 将党支部 日常管理与网络信息相结合。做好研究生党员信息化管理, 提高管理效率, 建立研究生党支 部成员基本信息资料库, 随时记录党支部成员和积极分子参加组织生活、学术文体活动等情 况, 作为评选优秀党员、预备党员转正、积极分子入党的一个重要依据; 建立网上党支部, 利用 $Q Q$ 群等网络应用开展网上党组织生活, 克服传统党支部活动受时空限制的不足, 为研究 生党建提供一个全新的空间。

总之, 应用创新思想, 积极建立学术科研型研究生党支部, 将党支部组织设置与专业设 置相结合, 结合学术科研开展形式丰富的党支部活动, 应用网络技术加强党支部日常管理, 将有利于研究生党支部的建设。

\section{致谢}

本文系武汉理工大学党建研究课题 “学校研究生学术科研型党支部创建研究” 研究成 果, 课题编号444-120057。

\section{参考文献}

[1] 潘建红, 贾钢涛. 创新研究生党建的思考. 学位与研究生教育 [J]. 2005.3

[2] 王舒. 构建科研型研究生党支部的探讨. 三峡大学学报 (人文社会科学版) [J]. 2008 年 12 月第 30 卷

[3] 党支部书记培训教材. 中共党史出版社 [M]. 2014 年 11 月修订

[4] 董艳. 积极构建高效研究生党建的四个平台. 学校党建与思想教育. 总第 301 期 